Meta

Journal des traducteurs

Translators' Journal

\title{
Analysing Irony for Translation
}

\section{Raymond Chakhachiro}

Volume 54, numéro 1, janvier 2009

URI : https://id.erudit.org/iderudit/029792ar

DOI : https://doi.org/10.7202/029792ar

Aller au sommaire du numéro

\section{Éditeur(s)}

Les Presses de l'Université de Montréal

ISSN

0026-0452 (imprimé)

1492-1421 (numérique)

Découvrir la revue

Citer cet article

Chakhachiro, R. (2009). Analysing Irony for Translation. Meta, 54(1), 32-48.

https://doi.org/10.7202/029792ar

\section{Résumé de l'article}

Cet article étudie pour la traduction et la traductologie l'utilité des

classifications et descriptions générales de l'ironie émanant des domaines de la critique littéraire, de la théorie littéraire et de la pragmatique. L’auteur suggère que les critères philosophiques et génériques adoptés dans ces domaines ne peuvent être appliqués à l'analyse de l'ironie dans la traduction, bien que la traduction de l'ironie soit un procès d'interprétation et de reformulation créative. C'est le cas en particulier quand on essaie de rendre l'ironie dans deux langues aux typologies différentes, telles que l'anglais et l'arabe, dans un type textuel spécifique, comme le commentaire politique. La traduction de l'ironie exige une approche plus objective et appliquée susceptible d'identifier les dispositifs formels et rhétoriques de l'ironie ; elle requiert, plus exactement, une analyse linguistique à même de mettre en relief, sur le plan de la phrase comme sur le plan du discours, la fonction communicative des textes d'ironie.
Ce document est protégé par la loi sur le droit d'auteur. L'utilisation des services d'Érudit (y compris la reproduction) est assujettie à sa politique d'utilisation que vous pouvez consulter en ligne.

https://apropos.erudit.org/fr/usagers/politique-dutilisation/ 


\title{
Analysing Irony for Translation
}

\author{
RAYMOND CHAKHACHIRO \\ University of Western Sydney, Sydney, Australia \\ r.chakhachiro@uws.edu.au
}

\section{RÉSUMÉ}

Cet article étudie pour la traduction et la traductologie l'utilité des classifications et descriptions générales de l'ironie émanant des domaines de la critique littéraire, de la théorie littéraire et de la pragmatique. L'auteur suggère que les critères philosophiques et génériques adoptés dans ces domaines ne peuvent être appliqués à l'analyse de l'ironie dans la traduction, bien que la traduction de l'ironie soit un procès d'interprétation et de reformulation créative. C'est le cas en particulier quand on essaie de rendre l'ironie dans deux langues aux typologies différentes, telles que l'anglais et l'arabe, dans un type textuel spécifique, comme le commentaire politique. La traduction de l'ironie exige une approche plus objective et appliquée susceptible d'identifier les dispositifs formels et rhétoriques de l'ironie; elle requiert, plus exactement, une analyse linguistique à même de mettre en relief, sur le plan de la phrase comme sur le plan du discours, la fonction communicative des textes d'ironie.

\begin{abstract}
This paper investigates the question of whether the classifications and general descriptions of irony, as true as they may seem, are plausible enough for enquiries into areas such as translation. The generic and philosophical analysis criteria provided by the literary criticism, literary theory and pragmatic approaches hover around broad interpretive models of irony. These criteria are impractical for the analysis of irony for translation purposes, although the translation of irony relies essentially on interpretation and creative reformulation. This is particularly the case when dealing with typologically distant languages, such as Arabic and English, in a specific text-type. To be able to "work" with ironic texts there is a need for a more objective and applicable approach, which considers the identification of formal and rhetorical devices of ironic texts, hence a linguistic analysis that explains the communicative function of these devices at both the utterance and discourse structure levels.
\end{abstract}

\section{MOTS-CLÉS/KEYWORDS}

irony, stylistics, discourse, speech acts, cooperative principle

\section{Introduction}

It seems an arduous, if not impossible task to tackle the analysis and translation of irony from a linguistic perspective. The linguistic and cultural differences between languages reflect discrepancies in the way speakers employ irony to express themselves. This renders the translation of irony as elusive as the concept of irony in itself and not amenable to traditional translation theories. Both overt and covert translations (House 1977), formal and dynamic equivalences (Nida 1964), and semantic and communicative translations (Newmark 1988) need to be considered. Both the writer's deviant stylistic choices and the reader's responses ought to be negotiated in the process and each militates against the other. Ironic devices are, at the functional level, 
authoritative devices of the original text that must be equally communicated. However, the substantial formal changes required to achieve functional equivalence run the risk of obliterating the source-text writer's idiosyncratic stylistic manipulation.

To address this dilemma, a review of the concept of irony in literary theory and pragmatic studies will be conducted and clues of ironic intentions in English and my other language, Arabic, will be identified. Relevant linguistic and stylistic notions are then explored for a workable analysis of ironic devices for the process of translation. Due to space limitation, a small number of examples from political commentary texts (PCTs) in Arabic and English published in Australia will be discussed for illustration.

\section{The concept of irony in literary theory and pragmatic studies}

To define irony in the context of this study, the distinction between irony, satire, sarcasm, wit and humour must first be established. The thin line between irony and sarcasm in PCTs, and the heavy reliance on explicit irony, bordering on sarcasm is assumed to be a function of the freedom of speech in the West, and in the case of most Arabic PCTs in Australia due to a feeling of alienation and hostility. Muir (1990) considers English humour a variety of irony that relates to the English culture, the environment of a free society and individuality. Humour is part of Arab life also; one can almost argue that humour kept the Arab spirit going in the darkest of recent times. Arabs laugh at their misery, whether it stems from political oppression or economic depression. Muir explains that certain forms of comedy in English share with irony a corrective purpose. However, irony differs strategically from comedy; the former is reserved and a means to an end, while the latter is public and an end in itself. With wit, irony shares language such as poetic references, paradoxes and puns. The definition of wit, as an upper social class offensive weapon classifies it as one of the devices of irony.

Booth (1974: 179n) believes "the distinction between irony, which must be ambiguous, and satire, which is making a clear point, depends entirely on one's definition." Muecke shares Booth's views. He sees nothing is gained "by confusing corrective irony with satire, which need not even employ irony.” (Muecke 1969: 28) Similarly, Booth states that only irony that implies a victim is ironic satire. He argues that "irony is used in some satire, not in all; some irony is satiric, much is not. And the same distinctions hold for sarcasm." (1982: 30) Muecke also considers that irony may function as "a weapon in a satirical attack" (1982: 3) while some sarcasm merely represents forms of irony, namely: "the crudest form of irony" (1982: 54), but only when the ostensible meaning is not the intended meaning. Muecke's definition of sarcasm relates to the tone in overt irony which "may be either congruous with the real meaning, and it is then that we have sarcasm or 'bitter irony,' or an exaggeration of the tone appropriate to the ostensible meaning, in which we speak of 'heavy irony'." (1982: 54) [Emphasis in original] Gibbs (1994: 384) also considers sarcasm as "an especially negative form of irony." Irony in PCTs identifies with Muecke's (1969: 232-233) notion of irony as a means related to satiric, heuristic and rhetorical ends. In other terms, ironic purposes in PCTs are 'given': mainly keeping politicians honest and calling for action; what is not, is the means: the signals provided by the writer to induce the addressee to presume that s/he "overtly speaks falsely." (Kauffeld 2001: 160) 


\subsection{Irony in pragmatic studies}

I now turn to recent pragmatic studies on this rather complex definition of irony for linguistic insight relevant to the present topic. Attardo (2000: 814) argues that a principle of "smallest possible disruption" of Grice's (1975) cooperative principle (CP) is put to work when irony is employed (See discussion on CP in section 3). He explains that limiting the violation of $\mathrm{CP}$ to the smallest possible context makes the violations tolerable and facilitates communication. (2000: 815) The examples below support the idea of minimal ironic devices to build discourse. Sperber and Wilson (1995: 239) consider that "the relevance of an ironical utterance invariably depends, at least in part, on the information it conveys about the speaker's attitude to the opinion echoed." This broad "echoic mention" (1995: passim) insight, i.e., referential property of utterances to something said or happened, is valid to critical analysis of verbal irony in PCTs.

Gibbs (1994: 362) considers that the understanding of verbal irony requires "shared sensibilities [between the speaker and the listener] about the subject being referred to," and suggests a number of devices that signal the possibility of irony in print typographical indices. He argues for the necessity of breaking Grice's (1975) truthfulness maxims and having a context of situation. Gibbs, Attardo and Sperber and Wilson do not venture, however, into a discussion on the type and role of linguistic devices in the formulation and reception of irony or the "interaction between [the] utterance, the hearer's accessible assumptions and the principle of relevance" required for the interpretation of utterances. (Sperber and Wilson 1995: 249)

Hutcheon (1995) takes a closer look at the concept and makes an important contribution to the analysis of irony by taking a holistic approach to the interpretation of irony in general terms, involving the interpreter of irony as an agent (see also Simpson (2004) below) and engaging him/her in a complicated interpretive process that includes the making of meaning and the construction of sense, with reference to "conflictual textual or contextual evidence or markers socially agreed upon." (1995: 11) These markers are activated by a 'discursive community' (1995: passim) whose interpreting expectations "are a function of the culture, language and social context in which both participants [the interpreter and the ironist] interact with each other and with the text itself." (1995: 91) The author makes extensive reference to the use of markers, clues, signals and triggers supplemented by various linguistic and communication theories and maintains that the interaction of the context with discursive community "provides a framing that makes signals, such as, quotation marks, understatement and echoic mention into markers of irony." (1995: 153) Hutcheon rightly considers that no lists of ironic markers can be provided given that the functioning of language cannot be separated with reference to any "absolute criterion of grammar or vocabulary," (1995: 154) and not even necessarily by relying on violations to Grice's (1975) conversational maxims. She suggests that certain markers act as triggers by having "a 'meta-ironic' function, one that sets up a series of expectations that frame the utterance as potentially ironic." (1995: 154) [Emphasis in original] Interestingly, Hutcheon proposes a second function of markers, that is, "to signal and indeed to structure the more specific context in which the said can brush up against some unsaid in such a way that irony and its edge come into being." (1995: 154) She hastens to doubt, however, the potential of this structuring function to lead directly to "a 
'reconstruction' of a latent and opposite or even 'true' meaning” (1995: 154), arguing that markers "simply act to make available...both the relational, inclusive and differential semantics and also that evaluative edge that characterize ironic meaning." (1995: 154-155) Considering the text type at hand, a more assertive claim to Hutcheon's general and cautious position on the structuring and interpretive function of ironic markers can be made on two accounts: 1) 'all' markers of irony in PCTs 'always' contribute to cohesion as well as coherence, i.e., to text development and rhetorical meaning, respectively. In other terms, they "function structurally to enable irony to happen in semantic and evaluative terms" (1995: 156), and 2) ironic markers 'must' rely on identifiable context of situation. The function of PCTs simply suggests that a commentary writer cannot in fact afford employing ambiguous ironic remarks in the development of their argument with recourse to the extreme of making a piece of literary art out of their article.

\subsection{Irony in satire}

Simpson also attempts to "build a generalised model of satire through a textual base that is derived largely from British popular satire" (2004: 112), which he claims to be "a macrosocial model of satire" (2004: 156-57). He admits, however, that the potential for the "generic" application of his model's categories remains to be proven. (2004: 112). Simpson, unhelpfully, considers satire as irony within irony and that the latter is "the space between what is meant and what is asserted," (2004: 91) and considers satire as a "multilayered mode of humorous communication" (2004: 43) (cf. definitions of irony and satire above) The author agrees with Hutcheon's (1995) holistic views in that "getting the point" of satire requires reaching a "macro-resolution' for the text as a whole and not just to reach a series of localised resolutions for individual embedded jokes." (2004: 43) [Emphasis in original] Following Foucault, Simpson argues that irony functions as "the infrastructure and determinant of the discourse," (2004: 83) and proposes for a satiric discourse to hold a three dimensional model in which irony plays a major role: the echoic prime or mention, which constitutes the first ironic phase; the dialectic dimension, which involves an "oppositional irony" (2004: passim); and the text processing stage, the "irony of conferral" (2004: passim), which involves the satiree. The author adopts philosophical concepts that depart from established linguistic and stylistic ones, although the model is claimed to be grounded in "linguistic pragmatics" (2004: 66) and stylistics in the "prime phase" and "dialectic dimension." See for example the mention of "text-internal elements as textual evidence for inferencing" (2004: 89-90), "style shift and incongruence as trigger of satirical footing" (2004: 103), "requisite stylistic ingredients for satirical composition" (2004: 141 and 145), "lexi-grammar features that realise satire" (2004: 142), and the interplay between "pragmatic framing devices [and] textual design and discourse organisation” (2005: 166).

This emphasis on style, structure and texture is not developed, however, neither through the analyses of the "symptomatic according to the analyst's judgement" (2004: 216) satirical excerpts taken mainly from Private Eye, the British satirical magazine, nor with the provision of linguistic explanations, which hinges on puns in humorous prose. Simpson employs a sociopolitical philosophical model on 'universal pragmatics' to try to account for his third ironic phase: the satirical uptake 
(2004: 158), where the application of Grice's (1975) seminal work on cooperative principle and Halliday's (1994) functional theory adequately, and more practically, cover his three validity claims, each of which has another "three interactive permutations - raising, recognising and redeeming." (Simpson 2004: 163) The author argues that "for satirical humour to work requires ultimately that irony be conferred on the discourse event by the satiree," (2004: 175) hence "the overall disposition of the satiree in the participation framework." (2004: 176) 'Participation' is also covered by Halliday's (1994) functional theory, and, more specifically, in stylistic/pragmatic analysis and translation models (e.g., Crystal and Davy 1969; House 1977). Other new terms covering ironic rhetorical devices (see below), described as "discourse techniques used in the formation of a dialectic component in satire" (Simpson 2004: 189), include 'saturation' and 'attenuation' instead of the well documented 'overstatement (hyperbole in rhetoric)' and 'understatement (litotes in rhetoric).'

Simpson's work falls into complex generalisation and his linguistic and claimed stylistic analyses (2004: 211, 215 and 219) do not materialise despite the many notions and theories invoked throughout the work to frame his model. Add to this, the confusion created by describing irony as a method or 'technique' in "satirical discourse" (2004: 53), although the author admits that "irony has an existence outside satire, but a particularly 'militant' version of it - one capable of targeting 'an object of attack'." (2004: 52-53) [Emphasis in original] Simpson realises the limitation of his model and the lack of rigorous analysis it provides and questions its validity and comprehensiveness when he describes his selection of a discourse-stylistic model as "open to question," adding in his closing remark that "more cognitive or more cultural, or even more political orientation in the framework of analysis would have yielded different insights and been more theoretically sophisticated." (2004: 219) This study is addressing Simpson's question.

From a translation study standpoint, the above review, in particular of Hutcheon's (1995) and Simpson's (2004) works, clearly indicates that relevant notions on irony in general and in PCTs in particular (i.e., militancy and object of attack), and, more importantly, the linguistic realisation of these literary notions have not been tackled or convincingly covered.

Modern linguistic translation theories commonly engage macrolinguistic approaches (e.g., language variations: temporal, geographic, participation, social role relationships, discourse rhetorical functions), coupled with microlinguistic ones (namely, textual realisation: texture, structure, grammar and lexis). These models are derived mainly from rigorous applications of disciplines such as discourse, text linguistics and stylistics (see section 2 below). On the other hand, the literary approaches to translation are traditionally perceived as unscientific given that their general hypotheses are not deduced from studies and empirical data (Delisle, 1982). The following section discusses the relevance and limitations of literary analysis and the application of linguistics to the inferencing and translation of irony in PCTs.

\subsection{The contribution of literary analysis to the notion of irony}

To this end, I turn to two major contributors to the literary analysis of the concept of irony, namely, Booth (1974) and Muecke $(1969,1982)$. Booth classifies irony in two forms: stable and unstable; each is divided into local and infinite on two levels: covert 
and overt (1974: 235). Stable irony involves two steps: the authors offer an unequivocal invitation to reconstruct and this reconstruction is not to be later undermined. (1974: 233) Unstable irony, on the other hand, implies that "no stable reconstruction can be made out of the ruins revealed through the irony." (1974: 240) Booth compares unstable irony to Muecke's general irony, who calls it "life itself or any general aspect of life seen as fundamentally and inescapably an ironic state of affairs." (Muecke 1969: 120) This paper will concern itself will the study of the specific irony: the corrective and normative (Muecke 1969) and stable irony.

Some of the clues Booth identifies in stable irony are: straightforward warning in titles, epigraphs, as well as parallelism and the juxtaposition of incompatibles; known error proclaimed using popular expressions, historical facts, conventional judgment; conflicts of facts within the work; clashes of style; and conflicts of beliefs or illogicality.

Muecke (1982) differentiates between two classes of irony: observable irony and instrumental irony. Instrumental irony is used when someone realises a purpose using language ironically, while observable irony could be unintentional and hence representable in art. Muecke (1969) distinguishes four modes of irony: impersonal, self-disparaging, ingénu (ingenuous) and dramatized, and gives impersonal irony the most prominent place and classification. Impersonal irony includes: praising in order to blame; blaming in order to praise; pretended agreement with the victim (of irony); pretended advice or encouragement to the victim; the rhetorical question; pretended doubt; innuendo and insinuation; pretended error or ignorance; ambiguity; pretended attack on the victim's opponent; and stylistically signalled irony.

Arabic literary theorists have not given the same comprehensive account of irony as their English counterparts. However, many reviews of the literary criticism theory of ancient Arab writers such as Al-Jahiz and Ibn al-Muqaffa' tackled the concept of irony in their style of writing. Mruwwah (1986) describes some of the tactics used by Al-Jahiz as follows: personification of the abstract, symbolism, exaggeration, irony displayed and insinuation. Al-Jahiz uses two modes of irony: ingénu and impersonal.

Various contemporary Arab writers, poets and playwrights also use irony as a tool to convey a message, conceal an opinion or simply to delight the reader or the audience. For example, Gibran Khalil Gibran uses antithesis, contrasting ideas, metaphors, synonymy, rhetorical questions and parallel structure. The Syrian playwright Muhammad Al-Magout uses contrasts, puns and cultural expressions.

It is noteworthy that the Arabic literary criticism theory includes many of the concepts described by Muecke $(1969,1982)$ and Booth $(1974)$ as ironic tools, albeit without a particular reference to irony, such as, praising in order to blame and blaming in order to praise.

To sum up, the above discussion raises three main issues that need to be addressed: 1) the limitations of universal interpretive models and general strategies in assisting the analysis of irony in general and for translation purposes in particular; 2) the need for practical linguistic criteria to assist in identifying and assessing ironic devices and their interaction with the immediate contextual meaning and overall message. These devices are analysable and some are predictable and even replicable as they become institutionalised. This agrees with Bally's (1952) claim that many expressive signs become socialised, and questions Hutcheon's generalisation that 
"nothing is an irony signal in and of itself"; (1995: 159) and 3) the issue related to the translator's dual role as a receptor and reproducer of such a complex stylistic tool.

Furthermore, the above reviewed literature highlights the importance of surface realisation of irony, albeit under different guises: clues, markers, signals to name a few, and emphasises the role of ironic devices, for the identification, inferencing and structuring of messages. Now, given the task of translating these text-/message-building devices, it is logical for this endeavour to invoke theoretical frameworks that address stylistic manipulation of linguistic and rhetorical devices, for insight that impacts on localised and discursive meaning. Translating is, ipso facto, a contrastive stylistic exercise, in which a source text is (ought to be) contrasted, at all its structural and textural levels, with a (supposedly) ideal, parallel (yet to materialise) target text. Therefore, a micro-macro approach ought to be adopted due to the fact that the starting point in the process of analysing irony in PCTs (the main ingredient for the formulation of message) is its stylistic features with due consideration to contextual and intertextual dimensions, while the translation of irony in these texts (the possible strategies with which the message can be communicated into the target language) starts from the analysed message but ultimately aspires to achieve a stylistic equivalent.

\section{A multi-disciplinary approach to ironic inferencing through stylistic manipulation}

Taylor (1981) argues that styliticians use the methodology of linguistic analysis but they begin their analysis from a general notion of the function of language in communication to set up the criteria by which there may be a particular stylistic function. By discussing poetry in general, Widdowson (1975) argues that the violation of formal structures of the language, whether in the use of metaphors or the oddities of the use of grammar, is evidence of the need for stylistic analysis to study the meaning in literary works. Widdowson sees the literary discourse as the link of the understanding of 'what' a work means to the understanding of 'how' it communicates.

Given the classification of irony in literature, and to account for notions in the literature on irony, such as, misrepresentation, pretended advice and euphemism, the focus will be directed to linguistic theories which address the analysis of the written language from a social interaction angle, or discourse. Sinclair and Coulthard (1975: 13) consider that in discourse the central level of language function is "the level of the function of a particular utterance, in a particular social situation and at a particular place in a sequence, as a specific contribution to a developing discourse."

Particular utterances encompass (and can refer to) formal stylistic devices, while particular social situations denote Enkvist's (1964) contextual restraints, and lastly, the particular place in a sequence indicates the role of formal stylistic devices in text development (Hatim 1989; Hatim and Mason 1990; Sa'addedin 1989) and in the process of arrangement of form and content (Nida 1990: 146-149). Viewing discourse from this angle we can assume that a discursive functional analysis is three dimensional: stylistic, sociolinguistic and rhetorical.

Halliday's theory of the functions of languages (1994) relates to the above three dimensions. The ideational function constructs a model of experience and logical relations; it implies that we must refer to our experience of the real world to encode 
and decode meaning. The interpersonal function enacts social relationships; it represents a progression from the semantic meaning to the pragmatic one, to text as a communicative intercourse vehicle. The textual function creates relevance to context through grammatical features, texture, structure and generic features of the text.

Let us try to apply Halliday's (1994) functional model to the analysis of the Arabic rhetorical device دوخن / 'made us dizzy,' in the following utterance:

\section{EXAMPLE 1}

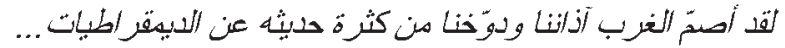

Literal translation: The West has deafened our ears and made us dizzy by its abundant talk about democracies...

The ideational function of the verb دوخخ / 'to make dizzy' stems from the following transformation: it is a feeling that one gets when a physical malfunction in the brain occurs as a result of sickness or malnutrition, fatigue, sea sickness etc. In the context of this article and bearing in mind the field of the discourse, another explanation must be considered, that is the metaphorical use. We know that Arabic speakers, unlike English speakers, use parts of the body (cf. deafened our ears) and physical senses as metaphors for emphasis. We know also that, in politics, the West is another metaphor that, in the real world, represents the ideologies, leaders, media and people of the West in general and not a specific geographical part of the world. Thus, دوخ / 'made us dizzy' refers to the effect of the daily Western pompous arrogance, in regard to its democracies, on 'us' feeling uneasy. Simply, this word seems to represent our real world as it is apprehended in our experience. Thus, the underlying meaning that we deduce is likely to be 'we are tired of hearing' because we are hearing it all the time.

The next step in the comprehension of the utterance is to consider the word from its function in the process of social interaction as a mode of doing, the interpersonal function. By assuming that 'we' is exclusive since it refers to the Arabs in general and Muslims in particular, and that 'he' refers to 'them,' the Western people and their views, and by reference to the experiential meaning of دو / 'to make dizzy' as interpreted above, then lastly by looking at the utterance as a conversation between an addresser and addressees we can suggest that the meaning is 'We reject and object to 'your,' i.e., the Western, claim of being the custodian of democracy in the world.'

The final aspect of meaning is the textual meaning of the word. The 'thematic organisation' of the utterance, to use Halliday's (1994) term, implies that the speech function of دوخّن / 'made us dizzy' is thematic, announcing the rejection of the claim and preparing the ground for a rebuttal (Hatim and Mason 1990) which is a feature of commentary writing. Furthermore, the use of the colloquial/standard verb / دوّخ / to make dizzy' is a tone marker of the speech that exerts on us an exaggerated illogical impact and gives an explicit indication of a potential ironic intention.

We can, tentatively, deduce from the discussion of the example above and in conjunction with the three dimensional discourse functions mentioned, an interpretive diagram for ironic devices in PCTs: 
FIGURE 1

Three dimensional discourse function

$\begin{array}{llll}\text { SITUATIONAL } & \text { DISCURSIVE FUNCTION } & & \text { CONTEXT } \\ \text { Field }= & \text { ideational, experience of the world, culture } & = & \text { stylistic } \\ \text { Tenor }= & \text { interpersonal, social relationship, pragmatic } & = & \text { sociolinguistic } \\ \text { Mode }= & \text { textual } & = & \text { rhetorical }\end{array}$

However, we still need to explain the reason 1 / 'made us dizzy' can be labelled as an ironic rhetorical device, and how one word can alter the conceptual meaning of an utterance giving it the true meaning that it has.

Fowler (1981) argues that Austin's speech act theory (1975) can initiate a formal explanation of our recognition of the force of devices. In the above example, the felicity condition, i.e., the requirement of a normal communicative channel was broken (cf. discussion on indirect speech acts and Grice's maxims below), when we encountered the colloquial/standard دوّخن / / 'made us dizzy' used in a metaphoric sense in writing. If we consider this a step further in line with Fowler's argument that literary discourse has marked and unmarked illocutionary determinants, the unmarked illocution would be 'I state that the West has made us sick by telling us ...,' while the marked illocutionary act would be 'we are tired of the West telling us ....' This also could be understood in the context of the commentary's argumentative text type as a rejection to the West's claim.

In Fowler (1981), two 'coincidental' overlaps come to light: 1) that the illocutionary acts parallel Enkvist's (1964) contextual meaning. Both share the view that a text has formal and explicit elements that determine text comprehension, such as, the use of pronouns and modality, and rhetorical and implicit elements, for example, repetition, metonymy and parallel structure. 2) Although discourse and stylistics treat texts from a pragmatic standpoint, discourse, unlike stylistics, emphasises the interactional features of texts, that is, social role relationships, participation and point of view. In other words, although stylistics is able to explicitly show the significance of the linguistic elements in the texts, it lacks the precision to explain, again linguistically, why parts of the literary style or discourse that we encounter are perceived as ironic. Discourse, following Fowler (1981: 88), is concerned not only "with the exact correctness of the paraphrase, but rather with the route by which we arrive at it, and, further, with the consequences of this route for our perception of illocutionary structure." [My emphasis] Based on this assumption, let us apply this point of view to the following understatement: سلمان رشدي المسكين / 'the poor Salman Rushdie' in the following utterance in an Arabic commentary text:

\section{EXAMPLE 2

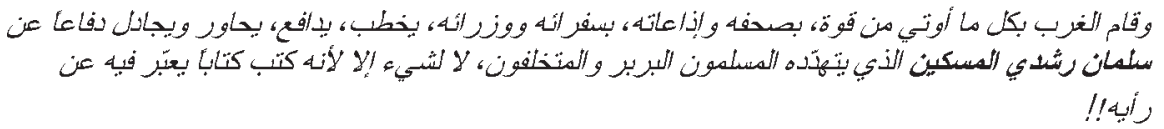

Literal translation: The West made every effort it has, through its press, its broadcastings, its ambassadors and ministers, to talk, defend, communicate and argue in defence of the poor Salman Rushdie, who is threatened by the barbaric and backward Muslims, just because he wrote a book in which he expresses his opinion!! 
According to stylistics, in its 'restricted context,' (Fowler 1981) the adjective 'poor' is a mark of irony, based on an impressionistic, behaviouristic view. However, communicatively, we can predict the utterance's double meaning from the semantic meaning of 'poor' against other devices in the immediate context (the other two ironic devices in the utterance: the self disparaging 'barbaric Muslims' and the overstatement using a run on of nouns and verbs 'press...defence'). Further, the ironic meaning of 'poor' is evoked from the preceding line of argument in the utterance, where the West is depicted as heroic in its relentless defence of the freedom of speech, with Rushdie symbolising that freedom. Textually, 'poor' constitutes a sign in one of two contradictory textual sets of sequences: 1) the pretended attack on the victim's (of irony) opponents (Muslims) in the battle for freedom of speech waged by the West in the above example; 2) the thesis in the introduction, which explicitly states the writer's opposing opinion about the West's claim of being the custodian of democracy (example 1 above is part of that thesis). This lexical/ textual analysis, ultimately, favours the illocutionary force that 'Rushdie is a victim of Western democracy' rather than the semantic meaning 'Rushdie is a victim of the oppressive nature of Islam.'

\subsection{Contribution of speech acts theory and cooperative principle to the interpretation of irony}

Assuming that irony is not liable to direct interpretation with reference to propositional meanings, as demonstrated by the examples above, Searle's indirect speech act (e.g., performing blaming with praise), that is, the real illocutionary force of the utterance, claim solution to the problem. Coulthard (1985), however, suggests the need to limit the number of ways a given indirect speech act is made through reference to "reality, the constraints of the situation and the current speaker's intentions for the progress of the succeeding discourse." (1985: 30) Although this limitation process reduces 'the choice' of interpretation, it requires, according to Coulthard, "an associated theory to explain how a listener comes to reject the direct interpretation and select the indirect one" (1985: 30). He proposes Grice's (1975) conversational maxims as the norms according to which we can screen utterances and establish their real inferences.

Written discourse is a two-way interaction, in which writers continuously 'membership' (Coulthard 1985) their readers to avoid misinterpretation. Irony in PCTs, which is, in the restricted sense, a form of linguistic ambiguity, has become a wellestablished colourful form of writing in the press. This typological framing seems, prima facie, to suggest one easy solution to a discourse analysis approach. Coulthard (1985: 44) argues that knowing the 'possible parameters' of the speech event, that is, the participants, situation and style gives the analyst great ability of expectancy. Having said that, we are left with a stylistic problem of irony, namely, the unlimited idiosyncratic and deviant (indirect) ways with which commentary writers use irony to achieve their rhetorical ends - be they comic, moral, corrective and/or hortatory - through textual, grammatical, lexical and graphological (see Gibbs 1994: 379) manipulation.

This normative deviance, hence difficulty, in classifying ironic strategies tangibly and objectively, suggest 'interpretive problems,' stemming from the 'openness' of the discourse acts, the realisations of which cannot be 'closely specified' (Coulthard 
1985). Searle approaches this lack of fit between grammar and discourse, in general, through the above mentioned indirect speech acts, while Sinclair and Coulthard (1975) suggest a sociocultural-structural approach based on 'a two stage interpretive process' about information related to 'situation' and 'tactics.' However, the authors (1975: 29) argue that "classification [of the illocutionary force of items] can only be made of items already tagged with features from grammar and situation." Coulthard (1985) gives an example of the application of this hypothesis to the interrogative grammatical category and suggests interpretive rules according to situational categories. These rules, the author admits, rely on "inferencing by listeners [/readers] and on appeal to shared world knowledge." (1985: 132)

Sinclair and Coulthard's (1975) setting of 'successful discourse rules' is plausible for an analysis of sanitised texts/speeches. However, suggesting the possibility of devising rules for grammatical categories in multifarious natural language situations, in ironic writing in particular, and, ultimately, to make use of these rules to interpret ambiguities, is obviously unachievable, simply because of the unpredictable variability of situations and open stylistic idiosyncrasies.

This circular argument begs a few questions. How can readers infer writers' intentions without having to resort to a complicated analysis process? Put differently, is this the natural process interlocutors, written or oral, follow when they attempt to produce or infer irony? For example, when an Arabic writer uses the expression / معلومات نابو ليونية

\section{EXAMPLE 3}

$$
\text { وبيدو أن معلومات السبا مورغان النابوليونية هي بمستوى مناجمه، أي تحت الارض ا... }
$$

Literal translation: It seems that Mr Morgan's Napoleonic information is at the level of his mines, that is, below the ground...

1) they are expressing a view about someone, 2) they have chosen to use an indirect style of attack, and 3) they are, more or less, disassociating themselves from the view expressed (Hatim and Mason 1990: 98-99). The writer here is charging his utterance with an unusual qualifier: 'Napoleonic' which, they assume will have impact and will be understood as exaggeration. Hence, the truth-value rests in the reverse of what is said. The Arabic reader, on the other hand, must also share the writer's strategic and linguistic competence, hence, inference theories presuppose a degree of competence the writer and reader (cf. Hutcheon's (1995) 'discursive community') must have for the success of discourse. The reader, however, first observes, to use my example above, the oddity (again violating the felicity condition) of the collocation: معلومات / 'information,' which in Arabic, normally collocates with سريّة/ 'secret'; مونوقة / 'reliable,' etc. Secondly, they deduce the pragmatic meaning of the adjective 'Napoleonic,' anaphorically, from the previous utterance, where the writer indirectly employs the same terminology (or its derivation) the victim of the irony (the subject of the attack in the article) used in an earlier statement (cf. Sperber and Wilson's (1995) 'echoic mention.' Loathing someone using their own words, is a strategy to protect one's views about this person. This strategy is quite common in our everyday conversations between friends or more formally when we deviously or amusingly talk about someone absent.

The following diagram shows a bi-directional text production/inferencing process of the utterance analysed above: 


\section{FIGURE 2}

\section{Bi-directional text production/inferencing}

Writer>

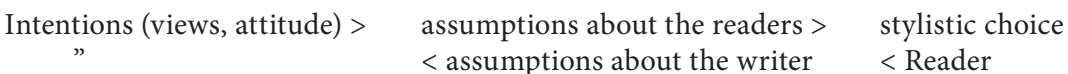

Grice's work (1975) had a great impact on the philosophical/pragmatic application to language analysis, using maxims that are writer/reader-oriented. They claim more universality than the speech acts, but are also based on inferencing and shared knowledge. Gricean conversational maxims have been the focus of attention of many discussions, albeit general, on irony (e.g., Sperber and Wilson 1995; Attardo 2000; Hatim and Mason 1990, 1997; Kauffeld 2001; Hutcheon 1995).

The co-operative principle which accounts for Grice's (1975) 'conversational implicature' is spelled out by four maxims, namely:

- quantity (a speaker should give the appropriate quantity of information);

- quality (information given should be correct or truthful);

- manner (expressions should be clear, non-ambiguous, brief and orderly); and

- relation (a speaker should maintain relevance to the subject matter and register).

Although irony in all its forms, ipso facto flouts the maxim of manner, on account of the presupposed indirectness, in English at least, by the fact that writers' ostensible meaning contradicts their intended one, still, the cooperative principle has useful application to the analysis of irony.

\subsection{The utility of Grice's cooperative principle to the translation of irony}

Grice's (1975) maxims represent the matrices according to which one can account for ambiguities in conversation. Following Coulthard (1985: 31), "these maxims do not represent a descriptive statement of how conversational contributions are," and speakers and writers violate them often for a variety of purposes. Giving this and the infinite possibilities of infringements, it is necessary to consider the violations that are likely to occur in ironic commentary writing to be prompted by stylistic devices for specific rhetorical purpose in a specific text type. Hence, there is need to define these specific violations. Bearing in mind that knowledge of the speech event, that is, the type of the discourse at hand, is a precondition to the assumption that irony is likely to be employed. We know that editorials deal with current affairs: political, economic, social etc., and that editorial writers wanting to express their views on these issues may be motivated (institutionally or personally), opinionated and analytical, targeting a readership which might share their expectations, inclinations and judgements. Moreover, both the reader and the writer share the stylistic features and norms of commentary text writing: length of text, structural and textural argumentative strategies, the implicit, detached and non-committal criticism, the corrective, hortatory message given between the lines, the colourful use of irony to get the message across in an implicit, concise and rhetorical manner (see also Hutcheon [1995: 18] on markers' implicitness and shared context), to name a few of the strategies commonly used in this form of writing.

This prior knowledge or expectation of the speech event plays a crucial role in identifying violations of Grice's (1975) maxims encountered in editorials and 
background features as ironic devices and not as mere rhetorical stylistic devices of argumentative texts in general. In other terms, distinction has to be made between irony in a specific text-type and irony in literature in general. Muecke (1996; 1982) and Booth (1974) as well as Grice (1975) focus on the general concept of irony and conversational norm breaching, respectively. Take the following expression using condition and contrast from a commentary:

EXAMPLE 4

Still, if nothing else, these extra challenges ${ }^{\star}$ should raise Fahey's profile.

[* Extra challenges refer here to the tasks of implementing a suspicious report by a Royal Commission into some building industry, aiming at 'destroying the power of the industry's union,' and appointing Fahey as a Housing Minister 'to clear up the mess of a Homefund scheme.']

This expression is considered ironic given the setting and its contribution to the utterance's role as a structural sign, i.e., substantiating the ironic thesis of the argument in the introduction of the article below:

WHEN you are in trouble, one of the golden rules of politics is to call for a report. It is an almost fail-safe way of defusing an issue. The only exception to this rule is when you are in deep, deep, deep trouble, in which case never call for a report because it may reveal the truth.

The utterance in example 4 is considered a violation of the maxim of quality, consistent with the 'pretended advice to the victim' strategy in the thesis: once Fahey [a Premiership hopeful] becomes involved in clearing up the 'mess of the Home fund scheme' and given that he is known as a man of reports, that is, an issue defuser, his handling of the issue will not only ease the pressure off the Premier's Government, but, ironically, will also boost Fahey's image at the electorate poll.

This clearly shows that maxim flouting strategy can serve as a trigger of irony. The real interpretation, however, involves considering this strategy in correlation with its context of situation, including the environment (political, social etc.), the usage of the language inventory and rules, and the text type convention (Hatim and Mason 1990: 48): grammar, lexis, texture, structure and style.

The interpretation of example 4 stems from the linguistic feature of the utterance, which employs a condition 'if' and implied contrast 'even.' The meaning of 'even if' is conveyed by if ... 'at least.' The formulaic habitual nature of the utterance has an experiential function. Interpersonally, there is an embedded opinion given its textual function as a cohesive device with an exophoric reference. The implied 'even' if nothing else ... 'at least,' gives the utterance its inference: Fahey is assigned the job of cleaning the mess, and 'he will benefit from it in the opinion polls'!

A suggested translation into Arabic can be processed as follows:

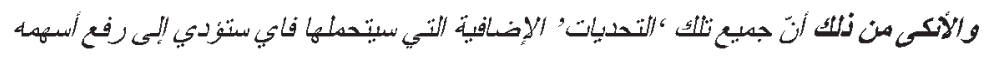

Back-translation: And what adds insult to injury is that all of these extra 'challenges' that Fahey will be charged with, will raise his popularity [literally: shares].

The ironic device used to instigate implicit doubt and dismay of the outcome in the English text with reference to a violation of a conversational maxim, has no linguistic equivalent in Arabic. The suggested substitute, however, provides an explicit doubt and disapproval into Arabic through a handy fixed expression commonly used in 
political commentaries. The experiential and interpersonal functions of the expression and the utterance provide the inference, without the need to invoke the cooperative principle. Other translations that warrant screening against the cooperative

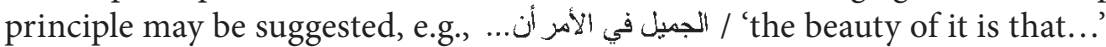

Below is another example highlighting the importance of style, structure, context of situation and conversational maxims in arriving at a plausible ironic inference and an equivalent in the target language.

\section{EXAMPLE 5}

Collins ${ }^{*}$ is an expert, in fact the champion, of avoiding trouble in the Greiner Government. Mud? He doesn't even know what it is, and if he did, he's had it dry-cleaned before anybody else saw it.

* [a former minister in the State of New South Wales, Australia]

There are three ironic devices in the above two utterances: 1) 'expert and champion': a rhetorical/lexical device featuring a praise in order to blame, realised by near-synonymy; 2) 'mud?': a rhetorical/grammatical device, realised by rhetorical question and reference; and 3) a metaphor realised lexico-grammatically by the compound adjective 'dry-cleaned.' The near synonymy 'expert and champion' is an overstatement with 'champion' calling on the readers' experience of its connotative meaning: 'the best,' which is also in textual contrast with the subsequent adjective 'trouble avoidance.' This device gives rise to the violation of the maxim of quality and irony. 'Mud' also has an evaluative and ironic effect, given the combination of its connotative meaning and the question mark. Also, the rhetorical question 'Mud?' is an anaphoric reference to political troubles in the text and has experiential function because of its exophoric reference to current affairs and common usage as a defamatory gossip, respectively. The use of the question form imparts an interpersonal function: the writer on the one hand is substantiating his thesis by way of a rhetorical question and on the other hand activating the participation of the readers, that is, by asking: 'do you think mud is affecting him [Collins]? Textually, Mud is a cohesive device of the main theme 'trouble, scandals, landmines' in the text. The little information the word is explicitly expressing infers a violation to the maxim of quantity. The verbalisation of the compound 'dry-cleaned' and its cataphoric reference to 'mud,' impart an innuendo, hence a violation of the maxim of manner and irony.

Communicating the above devices into Arabic requires a number of adjustments. For 'expert/the champion,' a grammatical change is warranted from the singular to plural to give the sense of exaggeration and to evoke the double meaning of 'con man,' which also compensate for the loss of the functional meaning of the definite article in 'the champion' used as an emphatic marker in English. Structurally, the coordinating conjunction 'in fact' preceded by a comma to embed the coordinate construction 'in fact the champion,' will have to be substituted by the equivalent in meaning but in form بأو ألأحرى both meaning 'or rather.' The second and third devices can be merged in Arabic. Mud's culture-specific meaning necessitates a substitute with a political corresponding meaning, e.g., مطبّات/ sticky situations [literally: pitfalls], which warrants, structurally and lexically, a change to the metaphoric compound 'dry-cleaned' (restricted to science in Arabic) in the answer. The compound can be compensated

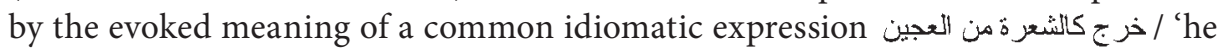


got out [of it] as a hair from the dough,' a probable collocate to هطبّات / 'sticky situations' in political discourse, hence it calls on the mutual shared experience between writer/reader in Arabic argumentative texts (Atari 1994). Aesthetically, the sentence boundary has to be extended, by the introduction of the explicit causative $\mathbf{i} /:$ 'for,' substantiating the thesis 'Collins is known as...' As a result, the question/answer reads as a direct statement but with similar utterance and discursive functions: 'Collins is corrupt and an expert in concealing his trouble,' but communicating irony using the expected plural for exaggeration and praise in order to blame cliché: 'to get out of...like a hair from the dough.' The Arabic runs as follows:

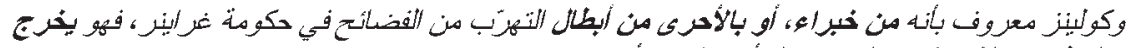

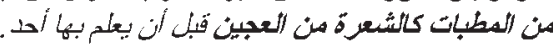

Back-translation: Collins is known as one of the experts, or rather one of the champions of evading scandals in the Greiner Government, for he gets out of sticky situations like a hair from the dough before anybody knows it.

The above analyses and discussion on the translation of ironic devices consider the fact that the readers' reactions to forms of language are based on expectations, including the violations of such expectations or 'emotive meanings.' (cf. Nida 1975) These violations encompass language, style and structure, as well as logic, hence go beyond the consensus among English scholars on irony about the significant role style and context play to encode and decode irony, with reference to philosophical interpretation of irony that marvels irony as a literary phenomenon beyond linguistic explanation. On the other hand, there are conflicting views among various approaches to irony, be it literary, pragmatic or psycholinguistic, about the extent to which Gricean's conversational maxims contribute to the making and perception of irony. For example, Sperber and Wilson (1995) consider that irony infringes all maxims, while Hutcheon (1995: 154) posits that "one cannot even argue that a violation of Grice's (1975) 'conversational maxims' will necessarily result in irony rather than confusion." The discussion on the examples above supports Hutcheon's (1995) position with regard to irony in Arabic but not English commentary texts. Irony in commentary writing in Arabic tends to be explicit if the newspaper or the journal enjoys a relatively free environment, e.g., in Australia, which gives writers a somewhat free reign to use explicit irony bordering on sarcasm. English commentators by contrast maintain conventional strategies that delight the reader but at the same time call for analysis and reading between the lines.

The theory of inference proves to be a plausible ground for the analysis and translation of irony in political commentary texts (see discussion on a model and strategies for the translation of irony in PCTs (Chakhachiro 2007). The speech acts theory provides a model that informs the illocutionary force or the ironic meaning of utterances and their discursive rhetorical function, with reference to ironic devices identified as such through their linguistic and stylistic properties and their conversational strategies based on Grice's cooperative principle, where applicable.

\section{Conclusion}

This paper highlights the indispensability of resorting to a hybrid of linguistic and sub-linguistic theories, namely: stylistics, functional, speech acts, logic and conver- 
sation and discourse, for the analysis of irony in political commentary texts for translation purposes. Stylistics accounts for the form the ironic text producers elect to convey messages; the functional theory considers style (and language in general) as a systematic resource for expressing meaning in context; modern styliticians have combined the above two notions suggesting a specific function to each stylistic choice based on social and cultural patterns, thus directing the spotlight to the context of situation. The theories of speech acts and conversation take us beyond the words, text, function and context to a philosophical world where certain rules are set to infer the meaning of what is being said. Feeding from various disciplines, form and function remain the focal point in the analysis and translation of irony.

This emphasises the need to develop a systematic bilingual competence of reception and production of irony in general and in specific text-types, in order to make plausible choices with reference to appropriate translation strategies of the linguistic manipulation inherent in ironic texts. The challenge is that although political commentary texts employing irony are constrained by contexts of situations and stylistic conventions, the margin, on the acceptability continuum, for "individual translation preference decisions" (Nord 1994: 66) is often large and requires disciplined analyses and high proficiency in the target language stylistic conventions.

\section{REFERENCES}

AtARI, O. F. (1994): “The place of communicative strategies in translating," Babel 40-2, pp. 6576.

Attardo, S. (2000): "Irony as relevant inappropriateness," Journal of Pragmatics 32, pp. 793 826.

Austin, J. L. (1962/1975): How to do Things with Words, Cambridge, Harvard University Press.

BALLy, Ch. (1952): Le langage et la vie, Genève/Lille, Droz et Giard.

Воотн, W. C. (1974): A Rhetoric of Irony, Chicago, University of Chicago Press.

СнакнасніRо, R. (2007): “Translating irony in political commentary texts from English into Arabic," Babel 53-3, pp. 216-240.

Coulthard, M. (1985): An Introduction to Discourse Analysis, London, Longman.

Crystal, D. and D. Davy (1969): Investigating English Style, London, Longman.

Delisle, J. (1982): L'analyse du discours comme méthode de traduction, in Cahiers de traductologie 2, Ottawa, University of Ottawa Press.

Enkvist, N. E. (1964): “On defining style: an essay in applied linguistics," in Spencer, J. (ed.), Linguistics and Style, London, Oxford University Press.

Fowlen, R. (1981): Literature as Social Discourse: The Practice of Linguistic Criticism, London, Batsford Academic and Educational LTD.

Gibbs, R. W. (1994): The Poetics of Mind, Figurative Thought, Language and Understanding, New York, Cambridge University Press.

Grice, P. H. (1975): “Logic and conversation," in Cole, P. and J. L. Morgan (eds), Syntax and Semantics, vol. 3: Speech Acts, New York, Academic Press, pp. 41-58.

Halliday, M. A. K. (1994): An Introduction to Functional Grammar, London, Edward Arnold.

Натім, B. (1989): "Argumentative style across cultures: Linguistic form as the realization of rhetorical function," in Babel: The Cultural and Linguistic Barriers Between Nations, Farmers Hall, Aberdeen, Aberdeen University Press, pp. 25-32.

Hatim, B. and I. Mason (1990): Discourse and the Translator, London, Longman.

Hatim, B. and I. Mason (1997): The Translator as Communicator, London/New York, Routledge.

House, J. (1977): A Model for Translation Quality Assessment, Tübingen, TßL-Verlag Narr. 
Hutcheon, L. (1995): Irony's Edge: The Theory and Politics of Irony, London and New York, Routledge.

Kauffeld, F. J. (2001): "Argumentation, discourse, and the rationality underlying Grice's analysis of utterance-meaning," in Enıкo, N. T (ed.), Cognition in Language Use: Selected Papers from the $7^{\text {th }}$ International Pragmatics Conference 1, pp. 149-163.

Mruwwah, H. (1986): Turathuna... kayfa na'rifuhu, Beirut, mu’assasat al-abhath al-'arabiyya. Muecke, D. C. (1969): The Compass of Irony, London, Methuen.

Muecke, D. C. (1982): Irony and the Ironist, London, Methuen.

Muir, F. (1990): The Oxford Book of Humorous Prose, From William Caxton to P.G. Wodehouse, Oxford, Oxford University Press.

Newmark, P. (1988): A Textbook of Translation, UK, Prentice Hall International.

Nida, E. A. (1964): Toward a Science of Translating: With Special Reference to Principles and Procedures Involved in Bible Translating, Leiden, E. J. Brill.

NidA, E. A. (1975): Exploring Semantic Structures, München, Fink.

NidA, E. A. (1990): “The role of rhetoric in verbal communications," Babel 36-3, pp. 143-154.

Nord, C. (1994) "Translation as a process of linguistic and cultural adaptation," in Dollerup, C. and A. LindegaArd (eds), Teaching Translation and Interpreting 2: Insights, Aims, Visions, papers from the Second Language International Conference (Elsinore, June 4-6, 1993), Amsterdam/Philadelphia, Benjamins.

SA'Adeddin, M. A. (1989): “Text development and Arabic-English negative interference," Applied Linguistics 10-1, pp. 36-51.

SeArle, J. R. (1969): Speech Acts: An Essay in the Philosophy of Language, London, Cambridge University Press.

Simpson, P. (2004): On the Discourse of Satire: Towards a Stylistic Model of Satiric Humour, Amsterdam/Philadelphia, John Benjamins.

Sinclair, J. McH and M. Coulthard (1975): Towards an Analysis of Discourse: The English Used by Teachers and Pupils, London, Oxford University Press.

Sperber, D. and D. Wilson (1995): Relevance: Communication and Cognition, Oxford/ Cambridge, Massachusetts, Blackwell.

TAYLOR, T. J. (1981): Linguistic Theory and Structural Stylistics, Oxford/New York, Pergamon Press.

Widdowson, H. G. (1975): Stylistics and the Teaching of Literature, Harlow, England, Longman. 